\title{
The Federal Photovoltaics Utilization Program: An Evaluation and Learning Framework
}

\author{
STUART L. HART*
}

Program in Urban and Regional Planning, The University of Michigan, Ann Arbor, MI 48109, U.S.A.

\begin{abstract}
The Federal Photovoltaics Utilization Program (FPUP) was established in 1978 with the belief that getting photovoltaic cells into the market was a "bootstrap problem" - one of eliminating market uncertainties through federal procurements to enable investments in improved production processes. A lack of clearly defined program objectives and expected results, however, was translated into continuing difficulties in implementation. Using the FPUP experience as an example, an alternative model of photovoltaic procurement is proposed which is simultaneously more structured (in that greater analytical control is used in selecting applications to fund) and more adaptive (in that continuous feed back is built in). A discussion of such a framework and sequential evaluation design is followed by some comments pertaining to the future of other commercialization efforts.
\end{abstract}

\section{Introduction}

This paper critically examines the Federal Photovoltaic Utilization Program (FPUP) - a 1978 program intended to speed the market penetration of photovoltaic technology through governmental procurements. Its purpose is two-fold: (1) to describe and evaluate the structure and conduct of the FPUP Program; and (2) to develop an alternative approach to photovoltaic (PV) procurement based upon the actual experiences of program implementation.

\footnotetext{
* The author is Vice-President and Senior Associate of the Research and Decision Center and Partner in Gordon Enk and Associates, both located in Medusa. New York. He is currently on leave at the University of Michigan.
} 
The evaluation suggests that a lack of clearly defined legislative objectives translated into problems with the intervention strategy and continuing difficulties in implementation. The proposed alternative program framework attempts to overcome these difficulties; it aims to accomplish simultaneously multiple objectives (e.g., reduce cost, stimulate innovation, encourage competition and develop performance data) by utilizing a quasi-experimental approach to procurement and building in continuous feedback loops from both procuring agencies and contracted industries. The observations made about the FPUP experience should be of interest to those concerned with policy implementation and to future designers of technology commercialization programs.

Section II begins by tracing the development of the FPUP Program in the context of federal energy policy and describes the program's approach, funding and conduct. Section III explores some of the problems encountered during implementation; these include the effects of changing social, economic and political environments, and problems with the theory of the intervention itself. Section IV proposes an alternative approach to program conduct based upon sequential evaluation, which enables the program resources to be directed at the potentially most productive applications. Section $\mathrm{V}$ describes in detail the nature of the alternative framework including a discussion of the intervention model, target population, measures of performance and the procurement design. The paper concludes (Section VI) with a few thoughts about the implications of the FPUP experience for future commercialization program design.

\section{The Evolution of FPUP}

In 1970, U.S. domestic oil production peaked and began to decline. In 1974, America received its first energy "shock" in the form of an oil embargo imposed by the OPEC countries. But despite rising prices and heightened insecurity, dependence on foreign oil has almost doubled since the embargo, now accounting for nearly half of U.S. oil consumption.

The two other traditional energy sources - coal and nuclear power - suffer from similar uncertainties. The development of nuclear power has been mired in controversy that goes beyond purely technical issues to considerations of personal conviction, social equity and political philosophy. Similarly, while the increased use of coal seems feasible given America's vast reserves, uncertainties about long-term, global environmental effects and more immediate problems of labor and management within the industry have resulted in a general reluctance to commit heavily to coal [2]. Given this climate of political uncertainty and rising costs, many of the non-conventional, alternative energy technologies begin to look more attractive. An important cluster of such alternative technologies are those broadly described as "solar energy" applications.

With the passage of the Solar Energy Research, Development and Demonstration 
Act (PL 93-473) in 1974, Congress laid what it intended to be the foundation for a billion-dollar federal solar energy program. As an initial step, it approved $\$ 75$ million for a national appraisal of commercially promising solar applications [3]. Among those applications designated for further consideration was photovoltaics - a system for the direct conversion of the sun's rays into electricity. In August, 1976, the Energy Conservation and Production Act (PL 94-385) was passed. Section 110 of the Act required the Federal Energy Administration (FEA) to "develop the policies, plans, implementation strategies, and program definitions for promoting accelerated utilization and widespread commercialization of solar energy." The most notable achievement spurred by the Act was the development of a commercialization plan for what had come to be regarded as one of the more attractive but difficult solar applications photovoltaics [4].

In 1977, the Department of Energy (DOE) became interested in increasing federal purchases of photovoltaic (PV) arrays and systems. Such an approach assumed that getting PV cells into the market was a "bootstrap problem." Elimination of market uncertainty through federal procurements would encourage companies to invest in improved production technologies that promised lower prices, which, in turn, would open up new markets [5].

Three laws mandated federal purchases of PV systems. The Department of Energy Act of 1978 - Civilian Applications (PL 95-238, Section 208) - made \$12 million available to purchase PV equipment for federal facilities. A Federal Photovoltaics Utilization Program (FPUP) was established by part 4 of the National Energy Conservation Policy Act of 1978 (PL 95-619). FPUP was set up as a procurement program for three years (FY 1979-81) and authorized at \$98 million. Finally, the Solar Photovoltaics Energy Research, Development, and Demonstration (RD\&D) Act of 1978 (PL 95-590) established a ten-year, \$1.5 billion federal commitment to photovoltaics. While this act initially encompassed PV purchases as well as RD\&D, President Carter, in 1978, recommended against a broad federal purchase program tied to this Act because he perceived research and development to be the most pressing priority [6]. With the advent of the new administration in January, 1981, most solar commercialization programs, including procurements, were slated for the chopping block [7]. Thus, at least during the Carter years, the Federal Photovoltaic Utilization Program (FPUP) constituted the centerpiece of federal PV procurement efforts.

FPUP was a program under which federal agencies were authorized to procure and install PV systems in federal facilities. Congress set forth the major objectives of the program to include:

1. Accelerating the growth of a commercially viable and competitive industry to make photovoltaic solar electric systems available to the general public;

2. Reducing fossil fuel costs to the federal government;

3. Developing performance data on the program; and

4. Stimulating the general use, within the federal government, of methods for the minimization of life cycle costs. 
Thus, the legislation (through the acquisition of PV systems by the federal government) sought to facilitate the use of low-cost production techniques by private suppliers, thereby fostering price reduction and increased market penetration of $\mathrm{PV}$ systems.

Congress authorized $\$ 98$ million to the DOE to be expended between October 1 , 1978 and September 30, 1981 for the purchase of up to 30 megawatts (MWp) of PV systems. Despite the authorization, however, only $\$ 25$ million was actually appropriated - \$15 million in FY 1979 and $\$ 10$ million in FY 1980 [8]. The money from the first two years was used to fund 2,760 applications within 26 federal agencies. The third year was dedicated largely to the processing and filing of agency reports on the actual photovoltaic applications, with few additional procurements being funded [9].

The Office of Solar Applications within DOE was responsible for overall FPUP administration. Technical, cost estimating, and policy supports for the program were provided by the Jet Propulsion Laboratory's Lead Center [10]. Other key actors in the FPUP Program included:

- Participating Federal Agencies;

- Photovoltaic Manufacturers; and

- The Program Review Advisory Committee.

The Program Advisory Committee (required by FPUP legislation) provided program oversight and was the entity responsible for recommending modifications to the program as deemed appropriate [11].

Federal agencies wishing to participate in FPUP were required to submit proposals to DOE for implementing their own projects if accepted by DOE. Responsibilities included not only the planning and purchasing of the actual equipment but also an elaborate system of reporting to DOE on system installation, performance, operation and maintenance.

The FPUP strategy called for five funding cycles over the allotted three year period, subject to the availability of funds (see Table 1). Each cycle included: solicitations for applications; application selection; transfer of funds; system procurements; installation and operation; and monitoring and assessment of system performance. Division of the program into such "funding cycles" reflected a recognition of the non-uniformity of potential PV markets.

Intertechnology Corporation [12] identified over 1,000 potential applications of photovoltaics. Another analyst [13] subdivided major PV markets into three categories: Near Term; Intermediate Term; and Long Term. Exemplary applications can be grouped according to this organizing principle (Table 2). Generally, Near Term applications are small-scale, remote applications that are currently cost-effective whereas Long Term applications are those that would have to compete with current large, grid-connected applications (e.g., industrial electricity) [14].

Although FPUP has now reached the end of its third and final year, it never moved significantly beyond the fourth funding cycle as outlined above [15]. While a few 


\section{TABLE 1}

FPUP Application Cycles*

\begin{tabular}{llll}
\hline Fiscal year & Cycle & Major applications & Cost-effective \\
\hline 1978 & I & Small remote & Late 1970s \\
1979 & II & $\begin{array}{l}\text { Small remote } \\
\text { Intermediate remote }\end{array}$ & Early 1980s \\
& III & Intermediate remote & \\
1980 & IV & Residential & \\
1981 & V & Selected inter- & \\
& & $\begin{array}{l}\text { mediate grid } \\
\text { connected }\end{array}$ & \\
& & &
\end{tabular}

*From U.S. DOE. 1979. "Federal Photovoltaics Utilization Plan," Pasadena: Jet Propulsion Laboratory (October).

TABLE 2

Market Categories for Photovoltaic Applications*

\begin{tabular}{lc}
\hline & Near term Market \\
$\begin{array}{l}\text { Microwave repeaters } \\
\text { Radio repeaters }\end{array}$ & Remote lighting \\
Buoys & Railroad crossings \\
Cathodic protection & Weather monitors \\
- pipelines & Digital fans \\
- bridges & Portable power \\
- structures & Battery chargers \\
Recreational vehicle systems & Long term market \\
$\begin{array}{l}\text { Intermediate Market } \\
\text { Water pumping }\end{array}$ & Residential electricity \\
$\begin{array}{l}\text { Outdoor lighting } \\
\text { Generator applications }\end{array}$ & Utility electrical generation \\
Village power systems & Commercial and industrial applications \\
\hline * Adapted from Morse et al. (1979). "Commercialization Strategy Report for Photo- \\
voltaic Systems." Washington D.C.: DoE; and Posner, David. 1979. "Photovoltaic \\
Markets: A Review and Assessment." Golden, CO.: Solar Energy Research Institute.
\end{tabular}

larger, grid-interactive systems were funded, most applications were systems which had not only been proven feasible, but had also been shown to be currently cost-effective. This preoccupation with cost-effectiveness, in conjunction with other associated factors, has raised many questions about the efficacy of FPUP in achieving its stated goals [16]. Before turning to an alternative approach to program definition and 
sequential evalutation, a brief discussion of the problems that were encountered by FPUP is necessary.

\section{Problems and Uncertainties in Implementation}

In 1977, the Solar Energy Research Institute (SERI) conducted a Photovoltaic Venture Analysis [17]. This study analyzed a proposed subsidy for private purchases of PV systems and concluded that such an approach was not an effective means of stimulating system cost reductions. Although there have been other studies focusing on the potential federal market for photovoltaics [18] beyond the work at SERI, little effort has been devoted to examining the impacts of federal purchase programs on the industrial and market development of photovoltaics.

Thus, while many purchasing programs have been proposed and one (FPUP) was carried out, a clear statement of the objectives and expected results of federal purchasing programs was not articulated [19]. Such ambiguity stemmed largely from the fact that the procurement model engendered in the FPUP program (and other proposals) was largely the brainchild of an overly ambitious Congress [20]. Indeed, FPUP's legislative history suggests that Congress was attempting to push a lethargic DOE into a more active stance regarding small-scale PV commercialization and use [21]. The resultant lack of clear objectives and a defined strategy was translated into continuing difficulties in interpretation and implementation which culminated in no appropriations for the third and final year. These difficulties and uncertainties can be grouped into three categories: changes in the environment during the intervention; difficulties arising directly from implementation; and problems associated with the theory of the intervention.

\section{Changing Environmental Context}

A diverse and evolving social, economic and political environment might have combined to alter or otherwise obfuscate the intention or effects of federal PV purchases. Areas of uncertainity include:

- Relative scarcity and costs of fossil fuels:

- Trends in the economy, especially inflation and interest rates;

- Status of competing electrical generation technologies;

- Trends in popular sentiment concerning conventional electrical sources;

- The ultimate size of the foreign market [22]; and

- The rate of technological innovation in the photovoltaics industry [23].

\section{Difficulties Arising During Implementation}

Several problems arose in attempting to implement FPUP as passed by Congress. Difficulties included: 
- Lack of specific criteria for determining which firms shall receive contracts. By allowing agencies to procure their own equipment, DOE effectively lost all control over which firms were given federal contracts and what size and form such contracts should take.

- Problems in specifying criteria for choosing which photovoltaic applications should be the focus of the program.

- Withheld appropriations. In its first two years, the FPUP Program received $\$ 25$ million of the initial $\$ 98$ million appropriation and no funding in its third year.

- Trade-offs with other programs. President Carter's statement recommending against a commercialization effort tied to the Solar Photovoltaic Energy RD\&D Act of 1978 set the stage for a greatly increased RD\&D at the expense of commercialization efforts [24]. Other trade-offs included conflicts with other electricity-generation programs, especially those related to the large, centralized solar-electric systems.

\section{Problems with the Theory of Intervention}

Many analogies have been made concerning the role that the federal government could play in PV technology and the role that the government played in the development of semiconductor technology in the 1950 and 1960s [25]. Indeed, substantial evidence exists to conclude that procurements were an effective means of encouraging integrated circuit and transistor technological advances and industrial development [26].

One SERI study [27], however, noted that early military procurements of semiconductors differed from PV procurements in the emphasis placed on technical achievement versus price reduction:

A distinguishing characteristic of Department of Defense purchase of semiconductors was their emphasis on performance, reliability and design requirements. DOD was willing to purchase innovative products at premium prices. When lower prices become the objective of government photovoltaic procurements, the stimulus provided by an early federal market that is more profitable and accessible than private markets is reduced. The introduction of cost reduction as the major objective of photovoltaic procurements is likely to change the influences that these procurements have on industry development [28].

Thus, the situation was no longer as simple as the early days of the transistor when the government was willing to pay high prices for technology that worked. As a result, the relationship between federal PV purchases and system cost reductions was unclear.

Another area of confusion and uncertainty regarding the theory of the program concerned the extent to which the FPUP Program could contribute to reaching DOE price goals for PV applications (see Table 3).

Beyond the fact that these price goals were set somewhat arbitrarily in 1973 during the crash "Project Independence" [29] and must therefore be of at least questionable 
TABLE 3

DOE Photovoltaic Module Price Goals*

\begin{tabular}{lc}
\hline Year & \$ per watt \\
\hline 1978 & $9-11$ \\
1982 & 2 \\
1986 & 0.50 \\
1990 & $0.10-0.30$ \\
\hline * Adapted from Fan, John (1978). “Solar cells: Plugging \\
into the Sun," Technology' Review (Aug./Sept.); and \\
U.S. DOE (1979). "Federal Photovoltaic Utilization \\
Program Plan." Pasadena: Jet Propulsion Laboratory.
\end{tabular}

validity, it has been stated that such cost reductions would require investment (in automated production lines with corresponding market volumes) of $100 \mathrm{MWp} /$ year [30]. The systems volume associated with FPUP for the full $\$ 98$ million would only have totalled 7.5 MWp despite Congressional authorization of $30 \mathrm{MWp}$ [31]. Thus, FPUP alone was clearly not capable of creating a competitive industry capable of selling cost-effective $P V$ systems. Furthermore, by focusing primarily on the reduction of PV module costs, the FPUP Program ignored important facets of the production process. Indeed, the DOE's FPUP Environmental Assesment estimated that only 45\% of PV system costs are accounted for by modules; the remaining $55 \%$ includes what is known as "balance of system" cost (e.g., power conditioners, storage capacity, structural supports, and other infrastructure) [32]. Despite DOE's efforts to encourage agencies to procure entire systems from single suppliers, the law's focus on module cost reduction inhibited system-wide considerations.

Another key determinant of future PV prices outside the realm of the FPUP Program was the availability and cost of the basic raw material. FPUP dealt exclusively with single crystal silicon solar cell applications. Because the PV industry uses less than $1 \%$ of the national silicon production, PV manufacturers are usually the last customers to be served by suppliers; and as demand increases, the result is higher prices [33]. Such price increases are due not to an absolute scarcity of silicon (which is the most abundant element on earth) but to inadequate capacity to produce the highly refined and energy-intensive semiconductor grade silicon needed for $\mathrm{PV}$ cell production [34]. Thus, by structuring the procurement program on the basis of a predefined declining price schedule, FPUP may have tried to encourage price competition and reduction that was not based on the real costs of production.

\section{Toward an Alternative Approach}

There was great potential in the FPUP Program for mid-course correction and learning. Since the program was authorized for FY 1979-81, a sequential evaluation of 
the program as it was implemented could have conceivably resulted in the restructuring of the approach for FY 1980 and 1981 and produced knowledge and information useful to future commercialization and procurement efforts. Such an approach to evaluation might be viewed as an iterative, flexible mechanism intended to direct the energy of the program to the most potentially productive applications. The overall goal of such an approach, therefore, would have been to structure a framework for evaluating the effects of federal PV purchases on industry using a collaborative approach involving DOE administrators, program staff, and representatives from the industry. By assuming an open, non-threatening posture toward the evaluation effort, the possibilities for mutual learning among all parties involved would have been greatly enhanced. While the current administration is basically averse to such direct intervention in the market place, it is at least feasible that a more analytically sound and economically effective model of solar commercialization would have fared better in funding levels. Specific objectives associated with the above approach would include a knowledge of:

- What would have happened without FPUP? That is, the establishment of a framework and process for determining the effects of the purchases made under FPUP on the PV industry to the one already established for monitoring and assessing the use of the PV systems by purchasing federal agencies.

- What are the alternative ways the FPUP money could be spent? Given the four major objectives contained in the legislation (see p. 327), what are the alternative methods of expenditures to achieving these goals?

- Which methods of procurement are most successful? Out of the various methods available for expenditure of FPUP funds, which are the most effective at achieving their intended objectives and what is their optimal mix?

- What approaches should be considered in the future? Based on the FPUP experience, a great deal of knowledge about procurement should be generalizable to other commercialization efforts.

\section{Structuring a Learning Framework}

Before describing the alternative approach in more detail, it is necessary to come to grips with some basic questions about the nature of the procurement program. These include specification of the intervention model, the target population, the measures of performance, and the assessment framework.

\section{The Intervention Model}

FPUP, as stated previously, differed markedly in its approach to technological change from most other RD\&D federal programs. Rather than focusing on the technical aspects of the device itself, this intervention model sought to manipulate the market 
for the device. The various hypotheses contained in this model might be summarized schematically as follows:

\begin{tabular}{|c|c|c|c|}
\hline $\begin{array}{l}\text { Allocation } \\
\text { of purchase } \\
\text { funds by } \\
\text { DOE }\end{array}$ & $\begin{array}{l}\text { Purchase of } \\
\text { photovoltaic } \\
\text { equipment by } \\
\text { federal } \\
\text { agencies; } \\
\text { reduction of } \\
\text { fossil fuel } \\
\text { costs }\end{array}$ & $\begin{array}{l}\text { Improved } \\
\text { production } \\
\text { capabilities } \\
\text { in the pri- } \\
\text { vate sector; } \\
\text { lower unit } \\
\text { cost; per- } \\
\text { formance data }\end{array}$ & $\begin{array}{l}\text { Growth of } \\
\text { competitive } \\
\text { photovoltaics } \\
\text { industry; in- } \\
\text { creased pur- } \\
\text { chases by } \\
\text { "general } \\
\text { public" }\end{array}$ \\
\hline
\end{tabular}

The Target Population

FPUP contained three levels of targets - federal agencies, private photovoltaic producers, and the "general public." In this context, it is important to distinguish between immediate targets and eventual targets. More specifically, the purchase of PV equipment by federal agencies from specific private firms was viewed as only a short-term objective intended to foster a longer term objective of making PV systems available to the public through enhanced industry competition and lowered market prices. Inherent in a purchase plan approach was a complex system of interactions entailing the transformation (or at least modification) of the entire electrical energy system, thus implying a diffusion process of broad and complex interactions [35].

Given the central importance of the PV industry in such a program, it might better be labelled an assistance effort rather than a procurement effort. But since the existing market for electricity is by no means uniform(e.g., dry cells versus electric generators), the task of specifying precisely the industry target group is difficult; only public utilities were specifically excluded from such efforts by the legislation. What was required is a more explicit statement of the specific firms or classes of firms being addressed by such a program.

\section{Measures of Performance}

Pertinent data to be collected for implementing the alternative approach can be usefully displayed according to variable type (Table 4).

The validity of these measures would appear to be quite high given the many complementary pieces of information about both firms and purchases. While reliability of the measures would not seem to be a problem for the independent variables (since they are all matters of public information), the dependent variables may suffer from reliability problems given the sensitive (and possibly proprietary) nature of the information being requested. 
TABLE 4

Data According to Variable Type

\begin{tabular}{|c|c|c|}
\hline \multicolumn{2}{|c|}{ Independent variables } & Dependent variables \\
\hline a) & $\begin{array}{l}\text { Characteristics of firm } \\
-\quad \text { size (No. of employees) } \\
-\quad \text { differentiation } \\
-\quad \text { growth rate } \\
-\quad \text { age } \\
-\quad \text { budget } \\
-\quad \text { profits } \\
-\quad \text { production capabilities } \\
\quad \text { (capitalization) } \\
-\quad \text { ownership }\end{array}$ & $\begin{array}{l}\text { a) Price of equipment } \\
\text { (application) } \\
- \text { unit prices } \\
\text { \$ per peak watt }(\mathrm{Wp}) \\
\text { S per unit of power }(\mathrm{KWh})\end{array}$ \\
\hline b) & $\begin{array}{l}\text { Characteristics of purchase } \\
-\quad \text { contract type } \\
- \text { contract size } \\
\text { absolute } \\
\text { relative to company sales } \\
\text { - contract duration }\end{array}$ & $\begin{array}{l}\text { b) Sale of equipment } \\
\text { (application) } \\
- \text { sales volume } \\
- \text { sales receipts } \\
- \text { market composition }\end{array}$ \\
\hline
\end{tabular}

We must be very leary of drawing causal links between immediate federal actions and distant societal changes. Indeed, the most socially meaningful connections are always the most difficult to measure and substantiate. Even the more direct influence of federal purchases on the PV industry per se must be subjected to close scrutiny since there are many other confounding and competing factors which might account for any apparent positive effect induced by the program. The problems associated with such "competing explanations of outcome" might be presented schematically as follows (see Fig. 1).

Let us examine these competing explanations a little more closely.

Competing Explanations. The critical evaluation issue is whether or not a program has produced more of an effect than would have occurred either without intervention or compared with alternative interventions [36]. In a sense, alternative explanations "compete" with the intervention as causes of the outcome. There are several factors which might have influenced the rate of commercialization of photovoltaics other than a procurement program. These include:

Long-term social trends: As society becomes aware of the problems inherent in the continued use of non-renewable energy resources and the dependence on foreign nations for energy supplies, there may be significant shifts to alternative, renewable 
Short term objective

$\begin{gathered}\text { Department } \\ \text { of } \\ \text { energy program }\end{gathered}$
Competing explanations
agurchases

Intermediate objective

Federal
agency
purchases

Long term objective

Photovoltaics
industry
production

Competing explanations

Fig, 1. Schematic of program causal links.

technologies. This might be coupled with a more general trend toward decentralism - a social vision which fits very well with small-scale on-site solar applications. Further, as electric utility companies experience increasing difficulties in the siting of large power plants, and costs rise accordingly, the trend may shift from one of centralized electrical production to decentralized service using PV as the principle technology.

Short-term intervening events: Several forces at large in society may have the effect of obscuring the effectiveness of the procurement program in accomplishing its objectives (not to mention yet unforeseen variables). Examples of general phenomena include:

- Overall economic trends;

- Costs of fossil fuels;

- Status of competing electrical generation alternatives (e.g., wind, biomass);

- Technological and cost breakthroughs in PVs (e.g., silicon production).

Examples of specific competing governmental programs include: 
- The Federal Photovoltaic Energy RD\&D Act (1978);

- The Experimental Technology Incentives Program (ETIP) [37];

- Residential and business tax credits (i.e., the National Energy Act);

- Utility regulations for peak load and declining block rate price reforms;

- Regulations and taxes discouraging oil and gas use;

- Federal loan guarantee programs.

Selection bias effects: The choice among many PV producers for purchases may have a profound effect on the ultimate outcome of the program. The mix of large, established producers with smaller entrepreneurial firms is an important variable in meeting the stated goals of a "commercially viable and competitive" industry. Providing strong financial incentives (in the form of purchase orders) to the most innovative or successful producers could stratify the industry into a handful of strong competitors and a myriad of marginal operations. This may be neither economically efficient nor socially desirable since a more "natural" development of the industry might lead to enhanced capabilities through competition. It is therefore critically important to consider not only which firms receive procurement contracts, but also the nature (i.e., size, duration) of the contracts themselves. Equally important is the need to monitor those firms who choose either not to bid for contracts or whose bids are rejected since the ability to secure a procurement contract may be influenced by factors other than potential production or innovation capabilities (e.g., company aggressiveness, proposal preparation capabilities).

Unreliability effects: The collection of reliable information from the PV producers may hold significant problems. As firms embark on innovative production courses, they may be unwilling to divulge fully their plans. Similarly, sales volume or information about growth and profits may be masked, making evaluation of industry changes very difficult. Further, the extent of unreliability of reporting may vary over the course of the program depending on the immediate business situation.

Evaluation-related effects: The mere act of monitoring and evaluating the performance of selected firms may result in sufficient notoriety to cause a significant disruption in the outcome. This "Hawthorne Effect" is by far the most difficult extraneous variable to treat.

The Evaluation Design. In an effort to isolate the effects of the procurement program from the competing explanations outlined above, a mixed strategy of non-randomized experiments with constructed controls in combination with before and after measures (reflexive controls) is recommended. Such a mixed approach seems appropriate since:

- the target population of firms is only slightly larger than covered by the program;

- the program has yet to be completely implemented, thus there exists sufficient 
"unexposed" targets (i.e., firms which have not received federal purchase contracts);

- time-series data on the industry should be relatively easy to accumulate; and

- given the multiple objectives and contract arrangements under the program, no single assessment methodology could embrace all desired program outcomes.

The first step is to develop a framework within which the various PV companies and contracting arrangements can be categorized (Fig. 2). The number of current and potential producers contained in the Fig. would not include all companies. Rather, the numbers in the Fig. would reflect only those firms (approximately 13-15) involved in some form of single crystal silicon PV R\&D or production; materials suppliers are excluded.

The next step is to collect time-series data (1970-present) on equipment sales and unit prices for individual producers and the industry as a whole. Such time-series information allows before and after comparisons of both individual firms (reflexive control) and the entire industry as well as providing the data necessary for the matching of similar companies to compare the effects of purchases (constructed controls). Such comparisons will enable the effects of "long-term social trends" and "short-term interventing events" to be isolated effectively following the intervention (i.e., the actual purchases).

Different contracting approaches could then be used to test the viability of the various objectives associated with the procurement program [38]. Large, multi-year, fixed-price contracts that specify progressively lower module prices could reduce the market uncertainties faced by participating companies and stimulate production investments leading to cost reductions. Companies with access to substantial capital backing would appear to be in the best position to bid on such risky contracts. Because

\begin{tabular}{|c|c|c|c|c|c|c|}
\hline $\begin{array}{c}\text { Financial backing } \\
\text { business status }\end{array}$ & $\begin{array}{r}\text { Engery } \\
\text { subs }\end{array}$ & $\begin{array}{l}\text { company } \\
\text { diaries }\end{array}$ & Electronic & s companies & $\begin{array}{r}\text { Small ph } \\
\text { fi }\end{array}$ & $\begin{array}{l}\text { otovoltaics } \\
\text { rms }\end{array}$ \\
\hline $\begin{array}{c}\text { Contract } \\
\text { type }\end{array}$ & $\begin{array}{l}\text { Current } \\
\text { producers }\end{array}$ & $\begin{array}{l}\text { Potential } \\
\text { producers }\end{array}$ & $\begin{array}{c}\text { Current } \\
\text { producers }\end{array}$ & $\begin{array}{l}\text { Potential } \\
\text { producers }\end{array}$ & $\begin{array}{l}\text { Current } \\
\text { producers }\end{array}$ & $\begin{array}{l}\text { Potential } \\
\text { producers }\end{array}$ \\
\hline Total no. of firms & 2 & 3 & 3 & 2 & 2 & 1 \\
\hline $\begin{array}{l}\text { Large, multi-year } \\
\text { purchases } \\
\text { (fixed cost) }\end{array}$ & & & & & & \\
\hline $\begin{array}{l}\text { Innovative product } \\
\text { purchases }\end{array}$ & & & & & & \\
\hline $\begin{array}{l}\text { Small, cost-based } \\
\text { purchases }\end{array}$ & & & & & & \\
\hline
\end{tabular}

Fig. 2. Design framework. 
the program seeks to foster a competitive industry and because it has been estimated that a purchase of at least $\$ 15$ million would be required to spur such investment [39], it is appropriate that only one such contract be made. The award could be made through a sealed bid approach with the potential for rapid market penetration being the major award criterion. Since only one such contract would be let, a "control" firm could be selected out of the pool of unsuccessful bidders based on a matching of important organizational characteristics (e.g., size, ownership, budget, growth rate, etc.) for the purposes of paired comparison. Although a number of intangible organizational characteristics are ignored when using such formal criteria, such a paired comparison would nonetheless offer an indication of the effects attributable to the large purchase.

Small, cost-based purchases could encourage many different companies to gain experience with a wide variety of PV systems [40]. Because of their small size and short duration, contracts for single applications would probably not stimulate industry production investments; such purchases would, however, provide valuable information to both suppliers and potential users on the performance of photovoltaic systems. Such a "stratified" method would ensure that all classes of firms would receive procurement contracts under the program and would help to mitigate the "selection bias" problem associated with the large multi-year contracts. Since the major purpose of such diverse purchases is to develop production experience and performance data on specific, promising PV systems, sales of contracted systems types could be monitored to see if any discernable increase is detected following the federal purchases.

Procurement of new module or system concepts using innovative production techniques might be a desirable component since significant cost reductions do not result from merely expanding existing production capabilities; what is required are production improvements to complete key production steps faster and at a lower cost [41]. Criteria for awards should be system performance and potential for large price declines; initial cost-effectiveness would not be of critical concern. Prices of those products procured could be monitored and compared with the prices of comparable products using traditional production methods. A simple before and after analysis could then be made of the prices of the equipment. Since both the innovative products and the "traditional" comparison product would be exposed to the same extraneous influences, most of the "competing explanations" would be controlled for except selection bias. The different contract types and their respective features are summarized in Table 5. To further minimize the "selection bias" problem, it may be also advisable to examine both those firms deciding not to become involved in the program, and those firms which submitted bids which were rejected. Examination of company leadership, organization, and skills may lead to some insights about what factors contribute to a firm's ability or inability to secure federal contracts.

Following all the federal purchases, information on unit prices and equipment sales should continue to be collected for a period of 1-2 years. Of particular interest should be who buys the equipment (above and beyond sheer sales volume). A changing mix of 
TABLE 5

Summary of Evaluation Design

\begin{tabular}{|c|c|c|c|}
\hline \multirow{2}{*}{$\begin{array}{l}\text { Contract } \\
\text { features }\end{array}$} & \multicolumn{3}{|c|}{ Contract type } \\
\hline & $\begin{array}{l}\text { Large, multi-year } \\
\text { purchase (fixed } \\
\text { cost) }\end{array}$ & $\begin{array}{l}\text { Innovative product } \\
\text { purchase }\end{array}$ & $\begin{array}{l}\text { Small, } \\
\text { cost-based } \\
\text { purchase }\end{array}$ \\
\hline Purpose & $\begin{array}{l}\text { Stimulate production } \\
\text { expansion; reduce } \\
\text { uncertainity; lower } \\
\text { unit costs for } \\
\text { modules }\end{array}$ & $\begin{array}{l}\text { Accelerate growth } \\
\text { of diverse and } \\
\text { competitive in- } \\
\text { dustry; stimulate } \\
\text { investment in } \\
\text { innovative methods }\end{array}$ & $\begin{array}{l}\text { Accelerate } \\
\text { growth of } \\
\text { diverse } \\
\text { and competi- } \\
\text { tive industry; } \\
\text { develop per- } \\
\text { formance data } \\
\text { on a variety of } \\
\text { systems; market } \\
\text { information }\end{array}$ \\
\hline $\begin{array}{l}\text { Criteria } \\
\text { for } \\
\text { award }\end{array}$ & $\begin{array}{l}\text { Well defined, cur- } \\
\text { rently marketable } \\
\text { applications } \\
\text { (cost-effective- } \\
\text { ness) }\end{array}$ & $\begin{array}{l}\text { Performance, reli- } \\
\text { ability and poten- } \\
\text { tial for large } \\
\text { price declines }\end{array}$ & $\begin{array}{l}\text { Performance, } \\
\text { reliability } \\
\text { and potential for } \\
\text { wide application } \\
\text { in the near and } \\
\text { immediate term }\end{array}$ \\
\hline $\begin{array}{l}\text { Selection } \\
\text { method }\end{array}$ & Sealed bids & $\begin{array}{l}\text { Active solicita- } \\
\text { tion; proposal } \\
\text { submission }\end{array}$ & $\begin{array}{l}\text { "Stratified" } \\
\text { competitive bids }\end{array}$ \\
\hline $\begin{array}{l}\text { Analytic } \\
\text { control }\end{array}$ & $\begin{array}{l}\text { Constructed } \\
\text { control- } \\
\text { paired com- } \\
\text { parison }\end{array}$ & $\begin{array}{l}\text { Before-and-after } \\
\text { analysis }\end{array}$ & $\begin{array}{l}\text { Reflexive } \\
\text { control - } \\
\text { system specific }\end{array}$ \\
\hline
\end{tabular}

purchasers in conjunction with increasing sales volume might suggest penetration of new markets. A strong trend of this sort among firms receiving federal procurement contracts might lead to connections between federal purchase and later market penetration and expansion. Such a connection would constitute the critical link between federal intervention and concomitant changes in the behavior of society at large.

\section{Conclusions}

While the overall goal of the Federal Photovoltaics Utilization Program (FPUP) was clear, it suffered from a lack of clearly defined objectives and expected results; there 
was no meaningful connection between individual procurement decisions and the "success" of the program from the standpoint of system cost reduction or market penetration. Indeed, most funded applications were systems which had not only been proven feasible, but also had been shown to be currently cost-effective. DOE's preoccupation with existing technology and current cost-effectiveness was in direct conflict with the goal of stimulating the technical and commercial viability of the PV industry. Further, by focusing primarily on reducing module costs, the program tried to encourage price competition and reductions that were not based on the real costs of production.

Despite the current political climate, it is nonetheless possible to learn a great deal from the FPUP experience. As suggested, DOE could have assumed more control over the procurement strategies to be used and the companies to be contracted by incorporating aspects of quasi-experimentation and sequential evaluation into its program design. This would have allowed the possibility for feedback and mid-course correction, thereby keeping the energy of the program directed at the most productive mix of applications. A more collaborative approach to program design and evaluation could have also greatly enhanced the efficacy of the program. By involving DOE administrators and staff as well as representatives from industry, the program could have been better assured of identifying and targeting the key variables and linkages involved in PV commercialization. By reducing the perceived threat associated with such efforts through early involvement and continuous feedback, program implementation (and evaluation) could move from a one-time, often post hoc pronouncement of success or failure, to an ongoing systematic learning effort.

Finally, the observations and suggestions made in this article about the FPUP Program can be readily generalized to numerous other federal programs intended to speed the market penetration of emerging of rapidly developing technologies. For example, the bulk of the solar commercialization programs of the 1970 s were plagued by many of the same problems of the FPUP Program. Most important among these problems was the over-concentration on currently available and cost-effective technology. Failing to recognize the dynamic nature of emerging technologies, such programs were largely unsuccessful at stimulating industry in the ways needed to speed effectively both the development and penetration of the technologies.

Federal procurement programs can facilitate the development of new technologies by providing an early market that is more profitable and accessible than private markets; when procurements are focussed on cost-effectiveness or price-reduction, however, the stimulus for experimentation and innovation is greatly reduced. It can only be hoped that future technology commercialization programs take stock of these past shortcomings. 


\section{Notes}

1 Stobaugh, Robert and Yergin, Daniel (eds.) (1979). Energy Future, New York: Random House.

2 See Schurr, S. et al. (1979). Energy in America's Future, Baltimore: The Johns Hopkins University Press; and Stobaugh ad Yergin (eds.), op cit.

3 Congressional Quarterly (1979). Energy Policy. Washington (April).

4 Federal Energy Administration (1977). "Preliminary Analysis of an Option for Federal Photovoltaic Utilization Program." Washington (July 20).

5 Commoner, Barry (1979). The Politics of Energy. New York: Alfred A. Knopf.

6 Carter, Jimmy (1978). "Solar Photovoltaic Energy Research, Development, and Demonstration Act of 1978," Weekly Compilation of Presidential Documents 14 (45) (Nov. 13).

7 See, for example, Norman, Colin(1981). "Reagan energy plan reluctantly unveiled," Science 213:520-522.

8 Smith, Elaine, FPUP Program Administrator, Department of Energy, personal communications on March 13, 1980, and September 19, 1981.

9 Ibid.

10 U.S. Department of Energy (1979a). "Federal Photovoltaic Utilization Program Plan." Pasadena: Jet Propulsion Laboratory (October).

11 Ibid.

12 Intertechnology Corporation (1977). "Photovoltaic Power Systems Market Identification and Analysis." Warrenton, VA (August 23).

13 Posner, David (1979). "Photovoltaic Markets: A Review and Assessment." Golden Co: Solar Energy Research Institute (June) SERI-TP-51-314.

14 Morse, F. et al. (1979). "Commercialization Strategy Report for Photovoltaic Systems." Washington, D.C. (draft) TID-28842.

15 Smith, Elaine, op. cit.

16 Hamilton, Thomas, Staff member of Jet Propulsion Laboratory, personal communication, March 13, 1980.

17 Costello, Dennis, et al. (1978). Photovoltaic Venture Analysis. Golden Co.: Solar Energy Research Institute (July).

18 For example, BDM Corporation (1977). "DOD Photovoltaic Energy Conversions Systems: Market Inventory and Analysis, Vol 1." Washington: Federal Energy Administration (June) and Federal Energy Administration, op. cit.

19 See Posner, David and Costello, Dennis (1980). Photovoltaic Procurement Strategies: An Assessment of Supply Issues. Golden Co: Solar Energy Research Institute, SERI-TR-352-298 (February).

20 Hamilton, Thomas. op. cit.

21 Hammond, Allen (1977). "Photovoltaics: the semiconductor revolution comes to solar," Science 156 (July 29) pp. 445-447.

22 See Battelle, (1979). "Export Potential for Photovoltaic Systems." Richland WA (April) DOE/CS0078.

23 See Kelly, Henry (1978). "Photovoltaic power systems: a tour through the alternatives," Science 199 (February 10) pp. 634-643.

24 Carter, J., op. cit.

25 See, for example, Commoner, B., op. cit; Stobaugh and Yergin (eds.), op. cit; and BDM, op. cit.

26 Examples include Braun, Ernest and MacDonald Stuart (1978). Revolution in Miniature: The History and Impact of Semiconductor Electronics. Cambridge: Cambridge University Press; and Utterback, James, and Murray, Albert (1977). "The Influence of Defense Procurement and Sponsorship of Research and Development on the Development of the Civilian Electronic Industry." Cambridge: MIT Center for Policy Alternatives (June 20).

27 Posner and Costello, op. cit.

28 Ibid, p. vi.

29 Kelly, H. op. cit.

30 U.S. Department of Energy (1979a), op. cit.

31 Ibid.

32 U.S. Department of Energy (1979b). "Federal Photovoltaics Utilization Program-Environmental Assessment." Washington: Assistant Secretary for Conservation and Solar Applications (May 15). 
33 Posner and Costello, op. cit.

34 Hammond, Allen, op. cit.

35 Schon, Donald (1971). Beyond the Stable State. New York: W. W. Norton and Co.

36 Rossi, Peter, et al. (1979). Evaluation: A Systematic Approach. Beverly Hills: Sage Publications.

37 See Tibbets, Roland (1978). "Small Business Innovation Applied to National Need." Washington: National Science Foundation (February).

38 For an expanded discussion of the different contracting approaches, see Posner and Costello, op. cit.

39 Ibid.

40 Ibid.

41 Ibid. 